\title{
PENGARUH MOTIVASI DAN KEMAMPUAN BERWIRAUSAHA TERHADAP KINERJA USAHA PEDAGANG KAKI LIMA DI KOTA KRAKSAAN.
}

\author{
Silvia Lorena \\ Department of Mangement FEB UMM \\ Email:Silvia@gmail.com
}

\begin{abstract}
The research purposes are to analyse the influence of motivation and entrepreneurship ability on business performance. Multiple linear regression used as a statictical tool. The result shows that motivation and enterpreneuship ability has strong influence on business performance. The recomendation from the analyses is management should maintain a good relationship with consumer and do some innovation regarding its business.
\end{abstract}

\section{Keywords: Motivation, entrepreneurship, and business performance}

\section{PENDAHULUAN}

Krisis yang melanda membuat motivasi masyarakat meningkat sehingga menimbulkan adanya dorongan dari diri sendiri untuk memulai usaha dalam memenuhi kebutuhan serta tuntutan sebagai tanggung jawabnya. Upaya untuk memanfaatkan peluang bisnis yang ada, mereka juga dapat berhubungan baik dengan pelanggan serta adanya urbanisasi maka usaha yang dimilikinya dapat berkembang pesat atau meningkat..

Kota Kraksaan ini dibatasi atas beberapa wilayah diantaranya sebelah timur yaitu desa Jabung Kecamatan Paiton, sebelah selatan ada Desa Patemon Kecamatan Krejengan, sebelah barat Desa Sukomulyo Kec.Pajarakan, sebelah utara selat Madura. Di desa Semampir ini terdapat banyak sekali pedagang-pedagang kaki lima yang awal mulanya mereka sebagai pedagang kaki lima keliling yang berjualan di tempat yang tak tentu. Dengan bertambahnya konsumen dan banyaknya penjual, maka seorang pedagang di tuntut untuk berkreasi dan inovatif supaya mereka dapat mencapai tujuan dan keinginan serta memberikan kualitas yang terbaik untuk konsumennya.

Motivasi, kemampuan berwira usaha terbukti memiliki pengaruh yang sangat signifikan terhadap kinerja usaha pedagang kaki lima, dibuktikan dengan hasil penelitian yang dilakukan 
oleh Apriana, 2010. menyatakan menunjukkan bahwa motivasi, kemampuan manajerial, kompetensi dan lingkungan secara simultan berpengaruh secara signifikan terhadap kinerja usaha pedagang kaki lima di Bekasi,

Teori ERG ini dikembangkan oleh psikolog Yale, Clayton Alderfer, adalah teori motivasi lainnya yang penting secara historis. $E, \quad R, G$ mewakili tiga kategori kebutuhan dasar, yaitu eksistensi (existance), hubungan (relatedness), dan pertumbuhan (growth). Kebutuhan eksistensi adalah kebutuhan yang diperlukan untuk kelangsungan hidup dasar mausia, secara kasar berhubungan dengan kebutuhan fisiologis dan keamanan dari hierarki maslow. Kebutuhan hubungan, yang melibatkan kebutuhan untuk berhubungan dengan orang lain, serupa dengan kebutuhan kebersamaan dan penghargaan milik Maslow. Akhirnya, kebutuhan pertumbuhan dapat disamakan dengan kebutuhan akan harga diri aktualisasi diri milik Maslow.

Penelitian ini menggunakan variabel motivasi dengan menggunakan teori ERG (mendeskripsikan kebutuhan eksistensi, hubungan, dan pertumbuhan) dan variabel kemampuan bewirausaha menurut Soemahamidjaja dalam Suryana (2013), sebagai variabel independen sedangkan variabel kinerja menjurut
Peter (1995 : 10) yaitu sebagai variabel dependen.

\section{TINJAUAN PUSTAKA}

Steinhoff dan Burgess (2004) mengemukakan enam karakteristik yang diperlukan untuk menjadi wirausahawan yang berhasil, yaitu memiliki visi dan tujuan usaha yang jelas,bersedia menanggung resiko waktu dan uang. Memiliki perencanaan yang matang dan mampu mengorganisasikannya.

Kinerja merupakan serangkaian kegiatan manajemen yang memberikan gambaran sejauh mana hasil yang sudah dicapai dalam melaksanakan tugas dan tanggung jawabnya dalam akuntabilitas publik baik berupa keberhasilan maupun kekurangan yang terjadi.Ivancevich (Ranto,2007:19).

Motivasi yaitu dorongan untuk pemenuhan kebutuhan eksistensi, hubungan dan pertumbuhan dan kemampuan dalam hal ini mengenai kemampuan beriinisiatif, kemampuan berinovasi dan kemampuan membentuk modal material dalam upaya untuk peningkatan kinerja usaha yang dilakukan oleh pemilik PKL yaitu mengenai hasil penjualan dan keuntungan atau laba.

Teori ERG ini dikembangkan oleh psikolog Yale, Clayton Alderfer, adalah teori motivasi lainnya yang penting secara historis. $E, \quad R, G$ mewakili tiga kategori kebutuhan 
dasar, yaitu eksistensi (existance), hubungan (relatedness), dan pertumbuhan (growth). Kebutuhan hubungan, yang melibatkan kebutuhan untuk berhubungan dengan orang lain, serupa dengan kebutuhan kebersamaan dan penghargaan milik Maslow.

Hal ini memberikan dukungan dalam upaya untuk meningkatkan pencapaian kinerja usaha dalam menjalankan berwirausaha yang meliputi: tingkat hasil penjualan dan tingkat keutungan.

Penelitian ini menggunakan variabel motivasi dengan menggunakan teori teori ERG (mendeskripsikan kebutuhan eksistensi, hubungan, dan pertumbuhan) dan variabel kemampuan bewirausaha.

\section{METODE PENELITIAN}

Jenis penelitian ini adalah penelitian deskriptif yaitu bertujuan untuk membuat deskripsi secara sistematis, factual, dan akurat mengenai fakta dan sifat populasi atau daerah tertentu. yang pada saat dilakukan penelitian yaitu berjumlah sebanyak 97 pedagang kaki lima. Populasi yang peneliti gunakan adalah pedagang kaki lima di RW 1- RW 06 di desa Semampir Kraksaan yang telah menjalankan usaha selama 1 tahun yang berjumlah 97 pedagang kaki lima.

Teknik yang digunakan dalam penelitian ini adalah studi lapang yaitu suatu cara untuk memperoleh atau mengumpulkan data dengan melakukan pengamatan secara langsung kepada objek yang bersangkutan.

\section{HASIL DAN PEMBAHASAN.}

Analisis rentang skala digunakan untuk mendeskripsikan kinerja motivasi dan kemampuan berwirausaha pedagang kaki lima didaerah Semampir Kraksaan. Rentang skala digunakan untuk mengetahui tingkat jawaban para pemilik usaha atas kondisi yang merasakan.

\begin{tabular}{|c|c|c|c|c|c|c|c|}
\hline \multirow[t]{2}{*}{ Itm } & \multicolumn{3}{|c|}{$\begin{array}{l}\text { Frekuensi } \\
\text { Responden }\end{array}$} & \multicolumn{2}{|c|}{ Jawaban } & \multirow{2}{*}{$\begin{array}{c}\text { Skor } \\
\text { Total } \\
\text { Indik } \\
\text { ator }\end{array}$} & \multirow[t]{2}{*}{$\begin{array}{c}\text { Penilai } \\
\text { an }\end{array}$} \\
\hline & $\mathrm{A}$ & $\mathrm{B}$ & $\mathrm{C}$ & $\mathrm{D}$ & $\mathrm{E}$ & & \\
\hline $\mathrm{X}_{1.1}$ & 16 & 53 & 28 & 0 & 0 & 376 & Tinggi \\
\hline $\mathrm{X}_{1.2}$ & 20 & 49 & 26 & 1 & 1 & 375 & Tinggi \\
\hline $\mathrm{X}_{1.3}$ & 7 & 23 & 20 & 17 & 30 & 251 & Rendah \\
\hline \multicolumn{6}{|c|}{ Total Skor Variabel } & 1002 & \\
\hline \multicolumn{6}{|c|}{ Rata-Rata Skor Variabel } & 334 & Tinggi \\
\hline
\end{tabular}

rentang skala yang disajikan pada tabel 4.6 di atas dapat diketahui total skor pendapat responden tentang variabel yang berkaitan dalam memenuhi kebutuhan sandang, pangan dan papan membuat terdorong untuk menjadi wiraswasta $\left(\mathrm{X}_{1.1}\right)$. Pada tabel 4.6 dapat diketahui bahwa sebanyak 16 responden atau $16,49 \%$ menjawab sangat setuju, sebanyak 53 responden atau 54,63\% menjawab setuju, responden yang menjawab cukup setuju sebanyak 28 responden atau $28,86 \%$, maka dapat diperoleh total 
skor sebesar 376 dengan kriteria tinggi. Kategori tinggi menunjukkan bahwa selama ini pemilik PKL memiliki motivasi yang tinggi dalam upaya untuk pemenuhan kebutuhan pokoknya.

Total skor pendapat responden tentang variabel berkaitan dengan banyaknya orang dan harus membina hubungan baik dengan orang lain membuat terdorong untuk menjadi wiraswasta $\left(\mathrm{X}_{1.2}\right)$. Pada tabel 4.6 dapat diketahui bahwa sebanyak 20 responden atau 20,61\% menjawab sangat setuju, sebanyak 49 responden atau 50,51\% menjawab setuju, responden yang menjawab cukup setuju sebanyak 26 responden atau $26,80 \%$, sebanyak 1 responden atau $1,03 \%$ menyatakan tidak setuju serta sebanyak 1 responden atau 1,03\% maka diperoleh total skor sebesar 375 dengan kriteria rendah.

Total skor pendapat responden tentang variabel mencapai kemajuan dan perkembangan maka secara mandiri membuat saya terdorong untuk menjadi wiraswasta $\left(\mathrm{X}_{1.3}\right)$. Pada tabel 4.6 dapat diketahui bahwa sebanyak 7 responden atau $7,21 \%$ menjawab sangat setuju, sebanyak 23 responden atau $23,71 \%$ menjawab setuju, responden yang menjawab cukup setuju sebanyak 20 responden atau 20,61\%, sebanyak 17 responden atau $17,52 \%$ menyatakan tidak setuju serta sebanyak 30 responden atau $30,92 \%$ maka dan diperoleh total skor sebesar 251 yang masuk dalam kriteria rendah. Berdasarkan hasil perhitungan rata-rata rentang skala diperoleh angka sebesar 334 yang berarti bahwa variabel motivasi pedagang kaki lima didaerah Semampir Kraksaan masuk dalam kategori tinggi. Makna dari hasil analisis rentang skala tersebut yaitu dengan rendahnya motivasi menunjukkan bahwa selama ini pemilik usaha memiliki motivasi yang rendah dalam pemenuhan kebutuhan eksistensi, merupakan pemenuhan kebutuhan pokok yaitu makan, minum dan perumahan, dorongan untuk pemenuhan kebutuhan hubungan dan dorongan untuk pemenuhan kebutuhan pertumbuhan, dorongan untuk mengembangkan usaha yang dijalankan.

Hasil analisis rentang skala variabel kemampuan berwirausaha dapat disajikan pada tabel berikut

\section{Tabel 2. Kemampuan Berwirausaha}

\begin{tabular}{|c|c|c|c|c|c|c|c|}
\hline \multirow[t]{3}{*}{ Item } & Frel & ensi & & & aban & \multirow{3}{*}{$\begin{array}{l}\text { Skor } \\
\text { Total } \\
\text { Indikator }\end{array}$} & \multirow[t]{3}{*}{ Penilaian } \\
\hline & \multicolumn{5}{|c|}{ Responden } & & \\
\hline & A & $\mathrm{B}$ & $\mathrm{C}$ & $\mathrm{D}$ & $\mathrm{E}$ & & \\
\hline $\mathrm{X}_{2.1}$ & 6 & 69 & 22 & 0 & 0 & 372 & Tinggi \\
\hline $\mathrm{X}_{2.2}$ & 4 & 28 & 34 & 17 & 14 & 248 & Rendah \\
\hline $\mathrm{X}_{2.3}$ & 27 & 48 & 11 & 10 & 1 & 381 & Tinggi \\
\hline \multicolumn{6}{|c|}{ Total Skor Variabel } & 1001 & \\
\hline \multicolumn{6}{|c|}{ Rata-Rata Skor Variabel } & 333,67 & Tinggi \\
\hline \multicolumn{8}{|c|}{$\begin{array}{l}\text { Berdasarkan hasil perhitungan rentang } \\
\text { skala yang disajikan pada tabel } 4.7 \mathrm{di} \\
\text { atas dapat diketahui total skor pendapat }\end{array}$} \\
\hline \multicolumn{8}{|c|}{ responden variabel ketika menjadi PKL } \\
\hline \multicolumn{2}{|c|}{ berupaya } & \multicolumn{2}{|c|}{ untuk } & \multicolumn{4}{|c|}{ memaksimalkan } \\
\hline
\end{tabular}


bahwa sebanyak 6 responden atau $6,18 \%$ menjawab sangat setuju, sebanyak 69 responden atau 71,13\% menjawab setuju, responden yang menjawab cukup setuju sebanyak 22 responden atau $22,68 \%$ dan sehingga diperoleh total skor sebesar 372 yang masuk dalam kriteria tinggi. Hasil tinggi menunjukkan adanya upaya yang tinggi para pemilik PKL untuk mengembangkan usaha yang dilakukan yaitu dengan mengembangkan potensi yang dimiliki sehingga usaha yang dilakukandapat mengembangkan poatensi yang dimiliki.

Berdasarkan hasil perhitungan rata-rata rentang skala diperoleh angka sebesar 333,67 yang berarti bahwa variabel kemampuan berwirausaha pedagang kaki lima di daerah Semampir Kraksaan yang telah diberikan perusahaan selama ini masuk dalam kategori tinggi.

Makna dari hasil analisis rentang skala yaitu dengan rendahnya kemampuan berwirausaha dalam hal ini mengenai kemampauan motivasi diri, merupakan kemampuan atas pengembangan potensi yang dimiliki pemilik PKL, kemampuan beriinisiatif, kemampuan menggali potensi yang dimiliki dalam melakukan pengelolaan usaha yang dilakukan dan kemampuan berinovasi, kemampuan selalu melakukan inovasi terkait untuk pengembangan usaha yang dimiliki.
Rendahnya kemampuan juga ditunjukkan dengan rendahnya dalam membentuk modal material untuk menghasilkan keuntungan secara maksimal dalam pengembangan usaha yang dilakukan.

Hasil analisis rentang skala mengenai kinerja usaha pedagang kaki lima yang ada di kota Probolinggo tepatnya di Semampir Kraksaan dapat disajikan pada tabel berikut:

Tabel 3. Kinerja Usaha (Y)

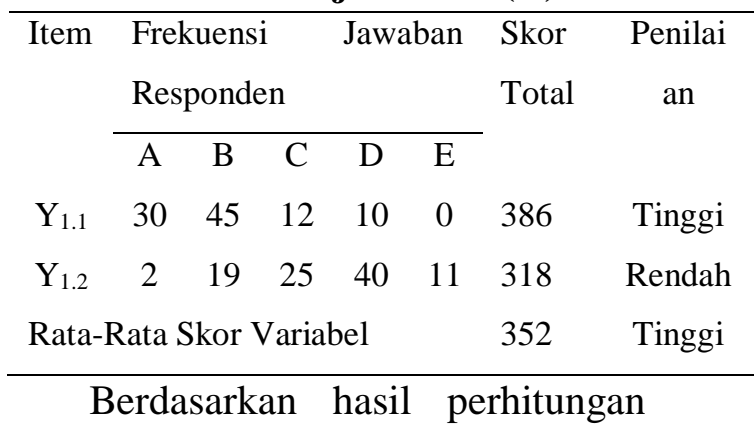

rentang skala yang disajikan pada tabel $4.8 \mathrm{di}$ atas dapat diketahui skor pendapat responden tentang jumlah pendapatan yang diperoleh dari hasil penjualan selalu menunjukkan adanya peningkatan usaha $\left(\mathrm{Y}_{1.1}\right)$. Pada tabel 4.8 dapat diketahui bahwa sebanyak 30 responden atau 30,92\% menjawab sangat setuju, sebanyak 45 responden atau 46,39\% menjawab setuju, responden yang menjawab cukup setuju sebanyak 12 responden atau $12,37 \%$, sebanyak 10 responden atau $10,30 \%$ menyatakan tidak setuju maka diperoleh total skor sebesar 386 yang masuk kriteria tinggi. 
Total skor pendapat responden tentang keuntungan dari aktivitas usaha selalu mengalami peningkatan dari waktu kewaktu (Y Y $_{1.2}$ ). Pada tabel 4.8 dapat diketahui bahwa sebanyak 2 responden atau 2,06\% menjawab sangat setuju, sebanyak 19 responden atau $19,58 \%$ menjawab setuju, responden yang menjawab cukup setuju sebanyak 25 responden atau $25,77 \%$, sebanyak 40 responden atau $41,23 \%$ menyatakan tidak setuju serta sebanyak 11 responden atau $11,34 \%$ maka dapat diperoleh total skor sebesar 318 yang masuk dalam kriteria rendah. Berdasarkan hasil perhitungan rata-rata rentang skala diperoleh angka sebesar 352 yang berarti bahwa keberhasilan usaha selama ini masuk dalam kriteria tinggi.

Makna dari hasil analisis rentang skala yaitu dengan tingginya kinerja usaha menunjukkan bahwa tingginya jumlah pendapatan yang diperoleh dari hasil penjualan dan tingkat keutungan, merupakan besarnya keuntungan dari aktivitas usaha yang dilakukan pemilik PKL.

Variabel independen dalam penelitian ini adalah motivasi dan kemampuan berwirausaha dan variabel dependen dalam penelitian ini adalah kinerja usaha pedagang kaki lima yang ada di kota Probolinggo tepatnya di Semampir Kraksaan. Dilakukan dengan program SPSS versi 13.0 for windows. Tingkat kepercayaan yang digunakan sebesar 95\% $(\alpha=0,05)$.

Makna dari hasil analisis data yaitu apabila terjadi peningkatan motivasi dalam hal ini terkait dengan pemenuhan kebutuhan eksistensi, merupakan pemenuhan kebutuhan pokok yaitu makan, minum dan perumahan, dorongan untuk pemenuhan kebutuhan hubungan dan dorongan untuk pemenuhan kebutuhan pertumbuhan, dorongan untuk mengembangkan usaha yang dijalankan maka kinerja karyawan akan mengalami peningkatan.

Jika $\mathrm{F}_{\text {hitung }}>\mathrm{F}$ tabel maka dapat disimpulkan bahwa terdapat pengaruh yang signifikan antara variabel-variabel bebas berupa variabel motivasi dan kemampuan berwirausaha secara bersama-sama terhadap variabel kinerja usaha pedagang kaki lima yang ada di kota Probolinggo. Hipotesis yang diajukan dalam penelitian ini adalah sebagai berikut: Variabel motivasi dan kemampuan berwirausaha terhadap variabel kinerja usaha pedagang kaki lima yang ada di kota Probolinggo. 


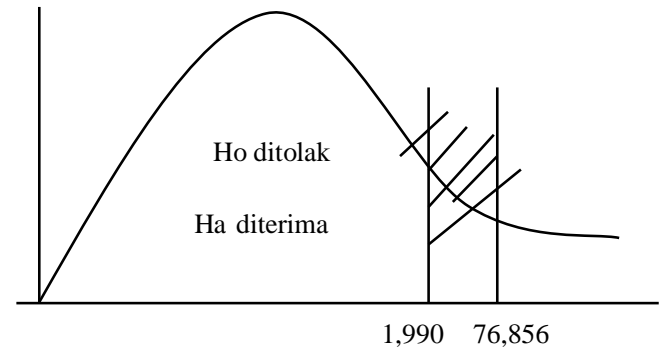

Gambar 1. Kurva Daerah Penerimaan Dan Penolakan $\mathrm{H}_{0}$ Untuk Uji F (Simultan)

\section{SIMPULAN}

Berdasarkan hasil penelitian dan pembahasan yang telah dilakukan maka dapat ditarik kesimpulan bahwa motivasi dan kemampuan berwirausaha pada kinerja pedagang kaki lima di Semampir Kraksaan masuk dalam kategori rendah, Kinerja usaha terhadap pedagang kaki lima di Semampir Kraksaan masuk dalam kategori rendah.

\section{DAFTAR PUSTAKA}

Buchari Alma. 2007,Manajemen Pemasaran \& Pemasaran Jasa.Bandung: CV. Alfabeta.

Hisrich, Robert D \&Petters, Michael P, 1995, Entrepreneurship, McGraw Hills, New York

Meredith, G. Gofery, 2005, Kewirausahaan Teori dan Praktek, Jakarta, Pustaka Binaman Pressindo.
Mangkunegara, Anwar Prabu. 2002. Manajemen Sumber Daya Manusia. Remaja Rosdakarya. Bandung. Mulyanto, 2007, Usaha Pedagang Kaki Lima, Universitas Negeri Yogyakarta.

Rivai, Vethzal \& Basri. 2005. Performance Appraisal: System Yang Tepat Untuk Menilai Kinerja Karyawan Dan Meningkatkan Daya Saing Perusahaan. Jakarta: PT. RajaGrafindo Persada.

Rante, Yohanes 2011. Pengaruh Perilaku Kewirausahaan dan Peran Pemerintah terhadap UKM Agribisnis. Jurnal Mitra Ekonomi dan ManajemenVol .2 no 1. April 2011; 1-17

Suryana. 2013. Kewirausahaan: kiat dan Proses Menuju Sukses. Salemba 4. Jakarta

Suryabrata, S, 2005, Metodolodi Penelitian, Jakarta: Radjagrafindo Persada.

Prof. Dr. H. Alma Buchari. 2008. Kewirausahaan. Alfabeta. Bandung. Ranto, Basuki. 2007. Analisis Hubungan antara Motivasi, Pengetahuan Kewirausahaan, dan Kemandirian Usaha terhadap Kinerja Pengusaha pada Kawasan Industri kecil di daerah Pulogadung. Jurnal Usahawan no 10 th xxxvi Oktober. 2007

Rina Irawati, 2012, Pengaruh kemampuan manajerial dan motivasi terhadap kinerja pewirausaha kecil/mikro melalui kepuasan kerja.

Sugiyono. 2007. Metode Penelitian Bisnis. Bandung; Al Fatah

Suryabrata, Sumadi. 2004. Metodologi Penelitian. Jakarta; Raja Grafindo Persada 
Suryana, 2013, Konerja Usaha Industri Kecil, Jakarta: Pustaka Binaman Pressindo

Widayat.2004. Metodologi Penelitian Pemasaran Aplikasi Software SPSS.Universitas Muhammadiyah Malang. Malang

Wisda Apriana dan Koranti, 2012, Analisis pengaruh motivasi, kemampuan manajerial, kompetensi, dan lingkungan terhadap kinerja uaha pedagang kaki lima di Bekasi

Yohanes, Rante, 2011, Kewirausahaan, Karya Ilmiah, Bekasi Genesis.

Zimmerer, W. Thomas And Norman M. Scarborough, (2002), "Pengantar Kewirausahaan Dan Manajemen Bisnis Kecil”, (Edisi Bahasa Indonesia) Jakarta. Jakarta : PT. Rineka Cipta 